\title{
EFFECT OF VARIOUS INDUSTRIAL WASTES ON MECHANICAL PROPERTIES OF CONCRETE
}

\section{SACHIN THAKUR \& ANKIT}

Research Scholar, Department of Civil Engineering, Chandigarh University, Gharuan, Punjab, India

\begin{abstract}
From decades it is common in construction to Consume natural resources. In construction industries, demand of construction materials is never come down and that is why there is need to focus on alternative construction material. If waste material like waste foundry sand, silica fume, glass powder is used as an alternative construction material then it can help to reduce the amount of disposal material. The research is conducted to compare concrete performance between conventional mix trial and a mix with addition of Waste Foundry Sand, Silica fume \& Glass powder in different concrete mix trial and check how concrete behave by addition of these (Waste Foundry Sand, Silica fume \& Glass powder in different concrete mix trial). By utilizing waste like waste foundry sand as a partial replacement of natural sand in concrete mix to create eco-friendly environment so that we can reduce the consumption of our natural resources. The replacement of cement with silica fume in small portions can be feasible due to the high reactivity of silica fume with calcium hydroxidethatis produced during the hydration of Portland cement. The experimental investigation was performed to evaluate the strength and durability properties of concrete mixture, a total of 4 concrete mix trial will be prepared and evaluate. First concrete mix trial will be made as a conventional mix trial. Second concrete mix trial will be made as are placement of naturals and with waste foundry sand by weight (10\%, 20\%, 30\%). Third mix trial will be made by taking the optimum value of WSF from trial second and silica fume is added with replacement of cement by weight $(5 \%, 10 \%, 15 \%)$. Fourth trial mix will be made as a replacement of natural sand with waste foundry by weight (taking optimum from trial second) and glass powder is added with a replacement of cement by weight of cement $(5 \%, 10 \%, \& 15 \%)$. Compression, split-tensile strength \& flexural strength test will be carried out on 7th, 14th, 28th, \&56thday. After evaluating the test result of each trial mix, finally we will compare the final result of each trial mix and see how concrete behaves in each concrete mix trials.

KEYWORDS: Concrete; Waste Foundry Sand; Silica Fume; Glass Powder; Compressive Strength; Tensile Strength; Flexural Strength
\end{abstract}

Received: Jun 10, 2020; Accepted: Jun 30, 2020; Published: Jul 16, 2020; Paper Id.: IJMPERDJUN2020355

\section{INTRODUCTION}

Concrete is the second most usable material used in the world. Concrete is a mixture of Cement, Fine aggregates, coarse aggregates and water. The cement is generally categorized as Ordinary Portland Cement and Pozzolana Portland Cement. The major part of cement comprises of Lime. The color of cement depends upon the oxides present in it. Concrete is mainly used in every construction field for the construction of Plain cement concrete structures and Reinforced cement concrete structures. Concrete possess high compressive strength and low tensile strength. It provides high rigidity and stiffness to a structure so that it sustains a longer life under uncertain loading condition. There are incredible researches carried out on the concrete by replacing it with some other materials like silica fume, fly ash and many more to accomplish high strength under cost- effective condition. In concrete the natural sand which is used as fine aggregate is taken from rivers directly. In order to accomplish the regular need 
and to decrease the consumption of natural sand, waste foundry sand can be partially substituted to natural sand by weight. As foundry sand is used in metal manufacturing factories as a mould in casting the ferrous and non-ferrous materials. Repetitively use of foundry sand as a mould leads it to loss of its binding property and then it is disposed as waste. But due to it is rich in silica it can be used as replacement of natural sand by weight to reduce the use of natural resources and contributing towards eco-friendly environment. Production of cement across the world increases day by day rapidly. Latest studies show that India is being on $2^{\text {nd }}$ place after Europe in producing cement. Incessant researches are being carried out across the world on new materials that can fully or partially replace cement. Silica fume is one such richly available material which can be used in spare of cement. As the silica fume has fine size particle which allows it to act as a filler and it also improve packing by entering the spaces between cement particles. Waste glass is another such richly available material which can be used in spare of cement. Whole of the glass waste can't be reused for making new glass, in fact most of the glass waste is usually disposed because of impurities present in it.

\section{Waste Foundry Sand}

Foundry sand is rich in silica sand and it is a by-product from the metal casting production of both non-ferrous and ferrous. As compared to natural sand which is used in construction the raw sand is generally of a better quality. The sand forms the outer shape of mould cavity during moulding process. This sand normally gets its binding property from the addition of small amount of bentonite clay. Green sand is the one when natural clays like bentonite or kaolinite binds the sand.

\section{Silica Fume}

Silica fume is a ultrafine powder which contains silicon content $75 \%$ or even more than this. The cement can be replaced partially by the silica fume as the ultrafine particle size will fill the voids of cement and also enhances the packing as it enters in the space between cement particles. Due to the high reactivity of silica fume with calcium hydroxide the silica fume can replace the cement. The bleeding, porosity, permeability of concrete can be lowered by adding of silica fume in it. The silica fume has pozzolanic properties and it is good in physical filling due to this effect makes it is widely acceptable as additional cementitious material. Calcium silicate hydrate is a valuable hydration product which can be produced with the reaction of highly reactive amorphous silica present in silica fume with calcium hydrate $(\mathrm{CH})$ and it provides great binding and strength properties in the cementitious materials.

\section{Glass Powder}

Waste glass is another such richly available material which can be used in spare of cement. Whole of the glass waste can't be reused for making new glass, in fact most of the glass waste is usually disposed because of impurities present in it. Crushed waste glass contains silicon in large amount. The waste glass has pozzolanic properties so the crushed waste glass can be used instead of cement partially. In the production of float, sheets, or containers soda lime glass are the common types of glasses. The existence of about $73 \% \mathrm{SiO}_{2}, 13 \% \mathrm{Na}_{2} \mathrm{O}$, and $10 \% \mathrm{CaO}$ in soda-lime glass makes it pozzolanic cementitious material so it can be properly used in concrete.

\section{MATERIALS AND TRIALS}

\section{Cement}

The most commonly used ordinary Portland cement is associated with the general term "concrete". All the trials on cement are done as per references of IS: 12269- 1989. Here are some of the test results of the OPC 43 grade cement. 
Table 1: Properties of Cement

\begin{tabular}{|c|l|c|}
\hline S N & \multicolumn{1}{|c|}{ Description } & Results \\
\hline 1. & The specific gravity of cement & 3.3 \\
\hline 2. & Fitness of Cement & 2.27 \\
\hline 3. & Initial Setting Time & 28 minutes \\
\hline 4. & Final Setting Time & 232 minutes \\
\hline 5. & Compressive Strength & 42.78 \\
\hline
\end{tabular}

\section{Aggregates}

Good quality aggregates ensure good quality concrete. In this study only the important parameters of aggregates are considered as per the guidelines laid down in IS 2386 (Part 1-8) for the testing of aggregates for concrete.

The properties of fine and coarse aggregates are mentioned in the below tabular forms.

Table 2: Properties of Coarse Aggregates

\begin{tabular}{|c|l|c|}
\hline S N & \multicolumn{1}{|c|}{ Description } & Results \\
\hline 1. & Fineness Modulus & 8.09 \\
\hline 2. & Specific Gravity & 2.64 \\
\hline
\end{tabular}

Table 3: Properties of Fine Aggregates

\begin{tabular}{|c|l|c|}
\hline S N & \multicolumn{1}{|c|}{ Description } & Results \\
\hline 1. & Fineness Modulus & 3.22 \\
\hline 2. & Specific Gravity & 2.61 \\
\hline 3. & Grade Zone & 2 \\
\hline
\end{tabular}

\section{Silica Fume}

Silica fume is the by-product resulting from the reduction of high purity coal, or in the production of silica and ferrous silica alloys. The silica fume is rich in amorphous silicon dioxide and consists of ultra fine spherical particles with average particle size about 100 times smaller than a grain of ordinary Portland cement.

Table 4: Properties of Silica Fume

\begin{tabular}{|c|l|c|}
\hline S N & Description & Results \\
\hline 1. & Diameter & $0.1-0.2$ microns \\
\hline 2. & Specific gravity & 2.3 \\
\hline 3. & Density & $150-700 \mathrm{~kg} / \mathrm{m} 3$ \\
\hline 4. & Surface area & $30000 \mathrm{~m} 2 / \mathrm{kg}$ \\
\hline
\end{tabular}

\section{Waste Foundry Sand (WSF)}

Waste foundry sand is used to replace natural sand and it was taken from Boparai metal casting, Mohali. The physical and chemical properties are shown in table 5 and table 6 respectively.

Table 5: Physical Properties of WFS

\begin{tabular}{|c|l|c|}
\hline S N & \multicolumn{1}{|c|}{ Property } & Results \\
\hline 1. & Specific gravity & 2.97 \\
\hline 2. & Fine modulus & 2.56 \\
\hline
\end{tabular}


Table 6: Chemical Property of WFS

\begin{tabular}{|l|c|}
\hline \multicolumn{1}{|c|}{ Constituents } & Value (\%) \\
\hline $\mathrm{SiO}_{2}$ & 87.91 \\
\hline $\mathrm{Al}_{2} \mathrm{O}_{3}$ & 4.70 \\
\hline $\mathrm{Fe}_{2} \mathrm{O}_{3}$ & 0.94 \\
\hline $\mathrm{CaO}$ & 0.14 \\
\hline $\mathrm{MgO}$ & 0.30 \\
\hline $\mathrm{SO}_{3}$ & 0.09 \\
\hline $\mathrm{Na}_{2} \mathrm{O}$ & 0.19 \\
\hline $\mathrm{K}_{2} \mathrm{O}$ & 0.25 \\
\hline $\mathrm{TiO}_{2}$ & 0.15 \\
\hline $\mathrm{P}_{2} \mathrm{O}_{5}$ & 0.00 \\
\hline $\mathrm{Mn} \mathrm{O}_{3}$ & 0.02 \\
\hline $\mathrm{SrO}$ & 0.03 \\
\hline $\mathrm{LOI}$ & 5.15 \\
\hline
\end{tabular}

\section{Glass Powder}

Waste glass is crushed to powder form and passed it from 75-micron sieve and then replaced it with cement. The property of glass powder is shown in table no 7 .

Table 7: Properties of Glass Powder

\begin{tabular}{|c|c|c|}
\hline S N & Property & Results \\
\hline 1. & Specific Gravity & 2.56 \\
\hline
\end{tabular}

\section{RESULTS AND DISCUSSION}

\section{Compressive Strength}

Compressive strength for concrete containing waste foundry sand and silica fume shown in fig 1 . The 28 days compressive strength for $0 \%$ Waste foundry sand\& $0 \%$ Silica fume show strength of $27.22 \mathrm{~N} / \mathrm{mm}^{2}, 28$ days compressive strength for $20 \%$ Waste foundry sand \& 5\% Silica fume show strength of $34.55 \mathrm{~N} / \mathrm{mm}^{2}, 28$ days compressive strength for $20 \%$ Waste foundry sand \& $10 \%$ sf show strength of $33.45 \mathrm{~N} / \mathrm{mm}^{2}, 28$ days compressive strength for $20 \%$ Waste foundry sand\& $15 \%$ silica fume show strength of $30.93 \mathrm{~N} / \mathrm{mm}^{2}$.

Compressive strength for concrete containing waste foundry sand and glass powder shown in fig 2 . The 28 days compressive strength for $0 \%$ Waste foundry sand\& $0 \%$ Glass powder show strength of $27.22 \mathrm{~N} / \mathrm{mm}^{2}, 28$ days compressive strength for $20 \% \%$ Waste foundry sand\& $5 \%$ Glass powder show strength of $26.84 \mathrm{~N} / \mathrm{mm}^{2}, 28$ days compressive strength for $20 \%$ Waste foundry sand\& $10 \%$ glass powder show strength of $28.23 \mathrm{~N} / \mathrm{mm}^{2}, 28$ days compressive strength for $20 \%$ Waste foundry sand $\& 15 \%$ glass powder show strength of $25.06 \mathrm{~N} / \mathrm{mm}^{2}$ 


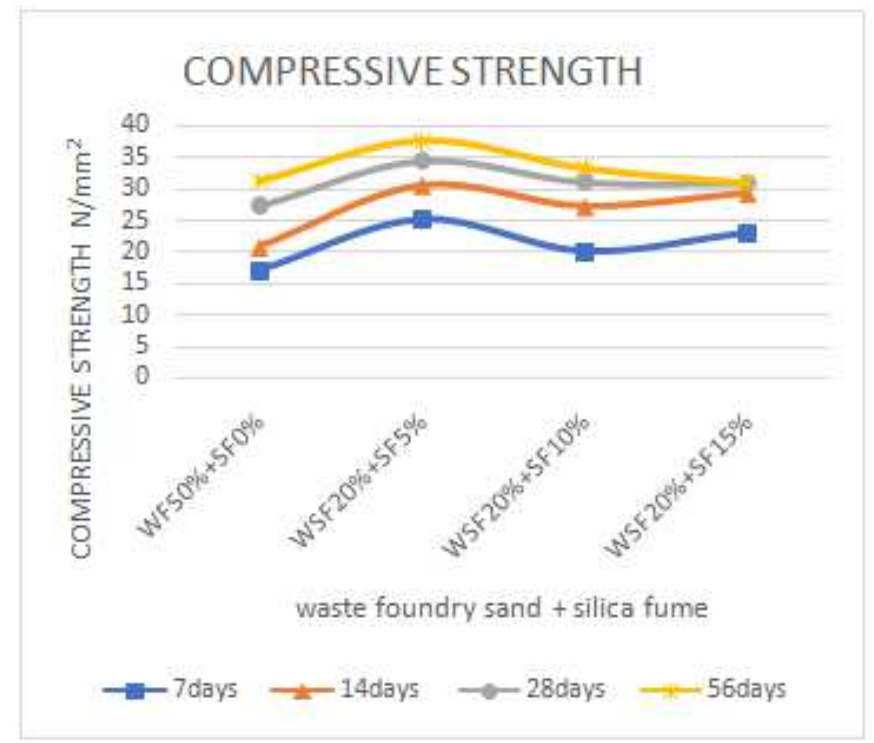

Figure 1: Compressive Strength in Relation with Waste Foundry and Silica Fume Content.

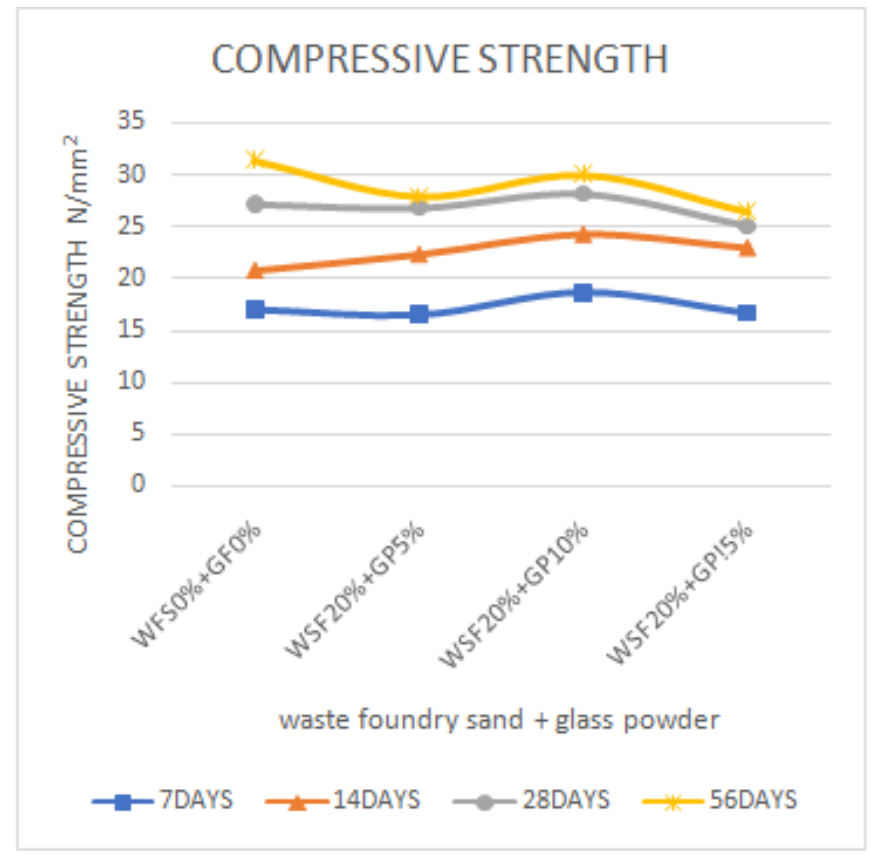

Figure 2: Compressive Strength in Relation with Waste Foundry and Glass Powder Content.

\section{Split Tensile Strength}

Split tensile strength for concrete containing waste foundry sand and silica fume is shown in fig 3 . The 28 days split tensile strength for $0 \%$ Waste foundry sand\& $0 \%$ silica fume show strength of $1.98 \mathrm{~N} / \mathrm{mm}^{2}, 28$ day split tensile strength for $20 \%$ Waste foundry sand\& $5 \%$ silica fume show strength of $3.40 \mathrm{~N} / \mathrm{mm}^{2}, 28$ days split tensile strength for $20 \%$ Waste foundry sand\& $10 \%$ silica fume show strength of $2.43 \mathrm{~N} / \mathrm{mm}^{2}, 28$ days split tensile strength for $20 \%$ Waste foundry sand\& $15 \%$ silica fume show strength of $3.14 \mathrm{~N} / \mathrm{mm}^{2}$.

Split tensile strength for concrete containing waste foundry sand and glass powder is shown in fig 4 . The 28 days split tensile strength for $0 \%$ Waste foundry sand\& $0 \%$ Glass powder show strength of $1.98 \mathrm{~N} / \mathrm{mm}^{2}, 28$ day split tensile strength for $20 \%$ Waste foundry sand\& $5 \%$ Glass powder show strength of $2.28 \mathrm{~N} / \mathrm{mm}^{2}, 28$ days split tensile strength for 
$20 \%$ Waste foundry sand\& $10 \%$ Glass powder show strength of $2.47 \mathrm{~N} / \mathrm{mm}^{2}, 28$ days split tensile strength for $20 \%$ Waste foundry sand\& $15 \%$ Glass powder show strength of $2.25 \mathrm{~N} / \mathrm{mm}^{2}$.

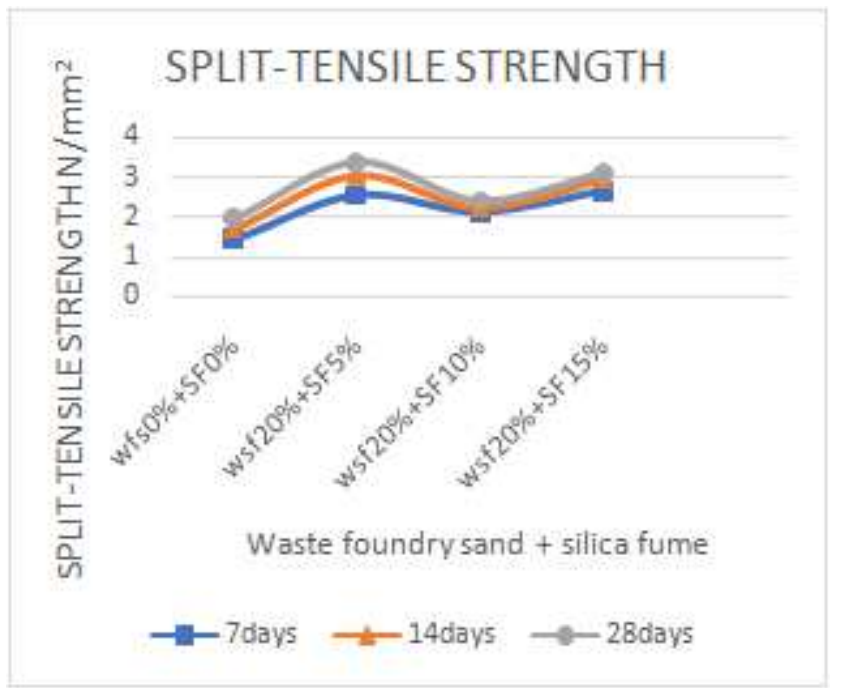

Figure 3: Split Tensile Strength in Relation with Waste Foundry and Silica Fume Content.

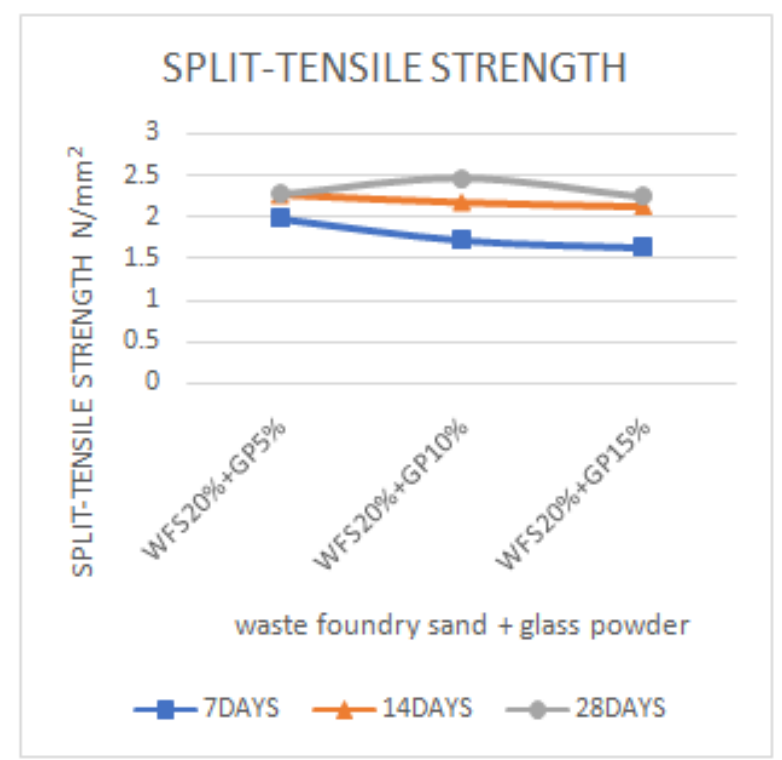

Figure 4: Split Tensile Strength in Relation with Waste Foundry Sand and Glass Powder Content.

\section{Flexural Strength}

Flexural strength for concrete containing waste foundry sand and silica fume is shown in fig 6 . The 28 days flexural strength for $0 \%$ Waste foundry sand\& $0 \%$ silica fume show strength of $1.98 \mathrm{~N} / \mathrm{mm}^{2}, 28$ day flexural strength for $20 \%$ Waste foundry sand\& $5 \%$ silica fume show strength of $12.2 \mathrm{~N} / \mathrm{mm}^{2}, 28$ days flexural strength for $20 \%$ Waste foundry sand\& $10 \%$ silica fume show strength of $11.5 \mathrm{~N} / \mathrm{mm}^{2}, 28$ days flexural strength for $20 \%$ Waste foundry sand\& $15 \%$ silica fume show strength of $12 \mathrm{~N} / \mathrm{mm}^{2}$.

Flexural strength for concrete containing waste foundry sand and glass powder is shown in fig 5 . The 28 days flexural strength for $0 \%$ Waste foundry sand\& $0 \%$ Glass powder show strength of $1.98 \mathrm{~N} / \mathrm{mm}^{2}, 28$ day flexural strength for $20 \%$ Waste foundry sand\& $5 \%$ Glass powder show strength of $14.56 \mathrm{~N} / \mathrm{mm}^{2}, 28$ days flexural strength for $20 \%$ Waste 
foundry sand\& $10 \%$ Glass powder show strength of $12.83 \mathrm{~N} / \mathrm{mm}^{2}, 28$ days flexural strength for $20 \%$ Waste foundry sand\& $15 \%$ Glass powder show strength of $14.03 \mathrm{~N} / \mathrm{mm}^{2}$.

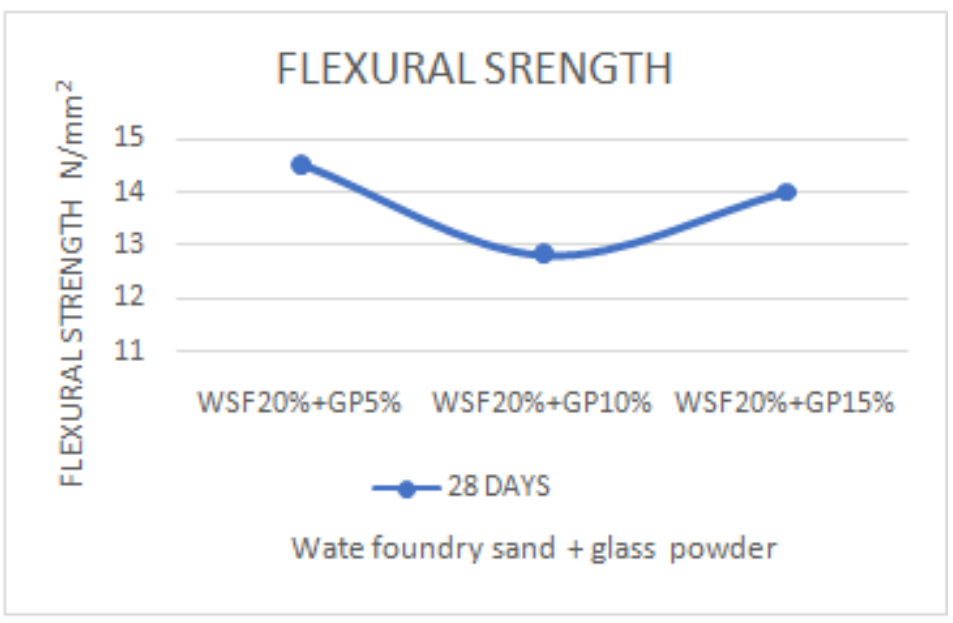

Figure 5: Flexural Strength in Relation with Waste Foundry Sand and Glass Fiber Content.

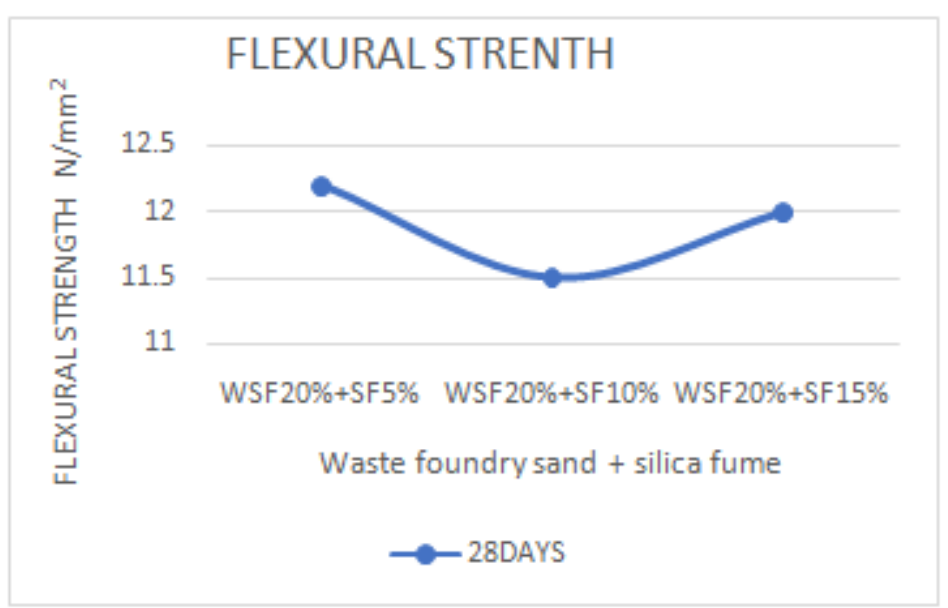

Figure 6: Flexural Strength in Relation with Waste Foundry Sand and Silica Fume Content.

\section{CONCULSIONS}

Following conclusion can be drawn from the present investigation:

- The 28 days compressive strength of Waste foundry sand and silica fume comes out to be $34.55 \mathrm{~N} / \mathrm{mm}^{2} \mathrm{maximum}$ at $5 \%$ replacement of silica fume with cement.

- The 28 days compressive strength of Waste foundry sand and glass powder comes out to be 28.23 $\mathrm{N} / \mathrm{mm}^{2}$ maximum at $10 \%$ replacement of glass powder with cement.

- The 28 days split tensile strength of waste foundry sand and silica fume comes out to be $3.40 \mathrm{~N} / \mathrm{mm}^{2} \mathrm{maximum}$ at $5 \%$ replacement of silica fume with cement.

- The 28 days split tensile strength of Waste foundry sand and glass powder comes out to be $2.47 \mathrm{~N} / \mathrm{mm}^{2} \mathrm{maximum}$ at $10 \%$ replacement of glass powder with cement.

- The flexural strength also comes out to be maximum at 5\% replacement of Silica fume with cement which is 12.2 $\mathrm{N} / \mathrm{mm}^{2}$. 
- The flexural strength also comes out to be maximum at 5\% replacement of glass powder with cement 14.56 $\mathrm{N} / \mathrm{mm}^{2}$.

\section{REFERENCES}

1. Y. Guney, Y.D. Sari, M. Yalcin, A. Tuncan, S. Donmez, "Re-usage of waste foundry sand in high-strength concrete”, Waste management Vol 30 (2010) P.p1705-1713.

2. G.H.L. Coppio, M.G.D. Lima, J.W. Lencioni, L.S. Cividanes, P.P.O.L. Dyer, S.A.Silva, "Surface electrical resistivity and compressive strength of concrete with the use of waste foundry sand as aggregate" construction and building material Vol. 212 (2019) P.p514-521.

3. N. Gurumoorthy, \& K. Arunachalam "Durability Studies on Concrete Containing Treated Used Foundry Sand" construction and building material Vol.201 (2019) P.p 651-661.

4. S. Hemavathi, A. Sumil Kumaran, R. Sindhu, "An experimental investigation on properties of concrete by using silica fume and glass fibre as admixture" Materials today: Proceeding

5. Guney, Y., Aydilek, A.H., Demirkan, M., 2006. Geoenvironmental behavior of foundry sand amended mixtures for highway subbases. Waste Management 26, 932-945.

6. Ferraris, M., Salvo, M., Smeacetto, F., Augier, L., Barbieri, L., Corradi, A., 2001. Glass matrix composites from solid waste materials. Journal of European Ceramic Society 21, 453-460.

7. Mehta \& D. K. Ashish "Silica fume and waste glass in cement concrete production" building engineering (2019)

8. J.M. Khatib, D.J. Ellis, Mechanical properties of concrete containing foundry sand, ACI Spec. Publ. 200 (2001) $733-748$.

9. R. Siddique, A. Noumowe, Utilization of spent foundry sand in controlled low-strength materials and concrete, Resour. Conserv. Recycl. 53 (2008) 27-35.

10. G. Singh \& R. Siddique "Effect of waste foundry sand (Waste Foundry Sand) as partial replacement of sand on the strength, ultrasonic pulse velocity and permeability of concrete" construction and building materials 26 (2012) P.p416-422

11. B. Bhardwaj \& P. Kumar "Waste foundry sand in concrete: A review" construction and building materials Vol. 156(2017) P.p661-674

12. El Haggar, S., El Hatow, L., 2009. Reinforcement of thermoplastic rejects in the production of manhole covers. Journal of Cleaner Production 17, 440-446.

13. G. Kaur, R. Siddique, A. Rajor, Influence of fungus on properties of concrete made with waste foundry sand, J. Mater. Civil Eng. 25 (2013) 484-490.

14. Al-Ameedi, Samer Hamid, Saba Mohammad Shaheed, and Mohammed Ali Mutar. "Investigate About Some Mechanical Properties of Hardened Concrete with Plastic and Metal Trash." International Journal of Civil Engineering (IJCE) 7.2 (2018):13-22

15. Aziz, Omar Q., and Bahman O. Taha. "Mechanical properties of high strength concrete (HSC) with and without chopped carbon fiber (CCF)." International journal of civil engineering (IJCE), 2.1 (2013): 1-12.

16. Sandhu, Rajindervir Singh, Jaspal Singh, and Gurpreet Singh Dhanoa. "Effect of Air Cooled Blast Furnace Slag and Polypropylene Fibre on Mechanical Properties of Concrete." International Journal of Civil, Structural, Environmental and Infrastructure Engineering Research and Development [IJCSEIERD] 5.3 (2015): 45-56. 
17. Kashiyani, Bhavin K., Jayeshkumar. Pitroda, and Bhavnaben K. Shah. "Innovative addition of polypropylene fibre in interlocking paver block to improve compressive strength." International Journal of Civil, Structural, Environmental and Infrastructure Engineering Research and Development (IJCSEIERD) 3.2 (2013): 17-26.

18. Tharun, Boorla, and Sreenu Ramavath. "INFLUENCE of Transverse Hole on Flexural Strength of RC Beam." International Journal of Civil Engineering (IJCE) 8.1 (2019):1-12 

